\title{
Political Anarchism and Raz's Theory of Authority
}

\author{
Bruno Leipold
}

Published online: 11 April 2015

(C) Springer Science+Business Media Dordrecht 2015

\begin{abstract}
This article argues that using Joseph Raz's service conception of authority to reject philosophical anarchism can be affected by political anarchism. Whereas philosophical anarchism only denies the authority of the state, political anarchism claims that anarchism is a better alternative to the state. Raz's theory holds that an institution has authority if it enables people to better conform with reason. I argue that there are cases where anarchism is an existing alternative to the state and better fulfils this condition. Consequently, in these cases, anarchist groups and societies and not the state have legitimate authority. When anarchism is not an existing alternative to the state, the state will, under Raz's theory, have some legitimate authority, but that authority will be limited because anarchism remains a better possible alternative to the state. To support the political anarchist claim I discuss the anarchist collectives during the Spanish civil war, which I argue are an example of anarchism as an existing alternative to the state that better fulfils Raz's service conception and also provide suggestive evidence that anarchism is in general a better possible alternative. I also discuss the relationship between political anarchism and authority and I argue that despite some tension they are not irreconcilable. I conclude that the interesting anarchist challenge for political theorists is political not philosophical.
\end{abstract}

Keywords Anarchism - Authority $\cdot$ Joseph Raz $\cdot$ Legitimacy $\cdot$ Spanish collectives

B. Leipold ( $\square)$

Department of Politics and International Relations, University of Oxford, Manor Road,

Oxford OX1 3UQ, UK

e-mail: bruno.leipold@politics.ox.ac.uk 


\section{Introduction}

The primary focus of debates about authority is philosophical anarchism, the claim that the state does not have legitimate authority. Indeed overcoming the "challenge of philosophical anarchism' has motivated much of the modern discussion of authority (Raz 1990, p. 4). The focus on philosophical anarchism has however often eclipsed and sometimes even hindered the understanding of political anarchism, the claim that anarchism is a better alternative to the state. Consequently the "challenge of political anarchism' usually plays only a minimal role in discussions of authority. I think this neglect is mistaken. The claim of political anarchism is not only in itself important but relevant to questions of authority.

I believe that this is particularly true of one of the most influential theories of authority, Joseph Raz's service conception. I will show that using Raz's theory to reject philosophical anarchism can be affected by political anarchism. ${ }^{1} \mathrm{I}$ argue that there are cases where anarchism is an existing alternative and better fulfils the conditions of the service conception than the state. ${ }^{2}$ Consequently, in these cases, if the political anarchist claim is true, Raz's theory does not reject philosophical anarchism but instead assigns authority to anarchist groups and societies. When anarchism is not an existing alternative to the state, the state will, under Raz's theory, have some legitimate authority, but because anarchism remains a better possible alternative to the state that authority will be limited to not preventing the promotion or establishment of anarchism. Consequently, in these cases, if the political anarchist claim is true, Raz's theory gives only a limited response to philosophical anarchism. Thus both in cases where anarchism is an existing alternative and when it is only a possible alternative, the state's authority and the extent of that authority is contingent on whether the claim of political anarchism is true. I support this through an extended discussion of the anarchist collectives during the Spanish civil war, which I argue are an example of anarchism as an existing alternative that better fulfils Raz's service conception than the state. This provides suggestive, but not definitive, evidence for the claim that anarchism is in general a better possible alternative to the state.

For the purposes of this article I largely accept Raz's theory of authority and my argument is hence mostly internal to it. ${ }^{3}$ I do not take a stand on whether his theory is the best way to understand authority or if political anarchists should in general have a theory of authority. My argument is thus primarily addressed towards those

\footnotetext{
${ }^{1}$ Gordon (2005, pp. 147-149) has argued that while Raz's argument might be a suitable response to philosophical anarchism it does not affect political anarchism.

${ }^{2}$ Krehoff (2008, p. 294) also suggests that non-state actors (such as international courts and non governmental organizations) could have authority if they fulfilled the service conception better than the state.

${ }^{3}$ I therefore do not engage with criticisms of the theory itself. These however include that it does not take into account the importance of democratic procedures to legitimate authority (Hershovitz 2003), skepticism about the role of exclusionary reasons (Darwall 2010), and that authoritative directives are not necessary for solving coordination problems (Green 1985). For an overview of Raz's critics see Ehrenberg (2011).
} 
that are sympathetic to Raz's theory, though I think the conclusions are of interest to discussions of authority more generally.

My argument is structured in five sections. First, I outline the main aspects of Raz's theory and then deal with how we should interpret the service conception when it comes to alternative institutions with a claim to authority. Second, I discuss the differences between philosophical and political anarchism and then set out what I mean by anarchism. Third, I present my core argument, where I show how using Raz's theory to reject philosophical anarchism is affected by political anarchism. Fourth, to support this, I turn to the historical evidence from the Spanish collectives. Finally I discuss the relationship between political anarchism and authority and argue that they are not irreconcilable.

\section{Raz's Service Conception of Authority}

At the heart of Raz's service conception of authority is the idea that authorities are legitimate if they help people do the right thing more than if people just acted on their own. This is articulated in more formal terms by his normal justification thesis, which states that:

the normal way to establish that a person has authority over another person involves showing that the alleged subject is likely better to comply with reasons which apply to him (other than the alleged authoritative directives) if he accepts the directives of the alleged authority as authoritatively binding and tries to follow them, rather than by trying to follow the reasons which apply to him directly (Raz 1986, p. 53).

An institution consequently has legitimate authority over someone else if the authority enables her to conform better with reason than if she tried to act on her own. ${ }^{4}$ Authorities are able to do this, Raz (1986, pp. 49-51) argues, because their power to issue authoritative directives that everyone must follow enables them to solve coordination problems and overcome prisoner's dilemma situations. In these situations it would be better if everyone stuck to one course of action, but if they just act individually they cannot guarantee this outcome. The institution derives its authority from the fact that it provides the 'missing link' in these cases, by ensuring that people will do the right thing ( $\operatorname{Raz} 1986$, p. 49). A straightforward example of this is how an authority can make an authoritative decision about whether people should drive on the left- or right-hand side of the road, which ensures that everyone follows this convention (Raz 1986, pp. 30-31).

Though my argument will focus mainly on the normal justification thesis, the service conception also includes two further theses. First, the dependence thesis,

\footnotetext{
${ }^{4}$ Raz's theory also applies to persons but I will henceforth only refer to the authority of institutions. I also understand institutions broadly so that it includes forms of social and political organisation. By legitimate authority I follow Raz (1986, p. 23) that it should be regarded as 'centrally involving a right to rule, where that is understood as correlated with an obligation to obey on the part of those subject to the authority.' I will occasionally say that an institution has 'authority' as a shorthand for 'legitimate authority'.
} 
which states that authorities should base their authoritative directives on reasons that already apply independently to people (Raz 1986, p. 47). For example, a law requiring parents to properly care for their children is based on parents' independent duty of care towards their child ( $\operatorname{Raz} 1986$, pp. 43-44). Authorities are hence illegitimate if they rule on the basis of reasons that do not apply to the people they govern or if they are worse or no better than if people acted by themselves. It is for this reason that Raz (1986, pp. 55-56) calls it the 'service' conception of authority, because it encapsulates the idea that authorities should serve the people they govern. Second, the pre-emptive thesis, which states that the authoritative directive of an authority excludes our other reasons for action, rather than just being added to other reasons (Raz 1986, p. 46). If we have for example referred a dispute to an arbitrator her decision will not just be one among many reasons to act, it is the reason to act, and excludes all our other reasons (Raz 1986, pp. 41-42). Finally, Raz sets a limit on the authority of an institution, arguing that it should not extend to those areas of life where there is an 'intrinsic desirability of people conducting their own life by their own lights' (Raz 1986, p. 57). Raz (1989, pp. 1180-1181; 2006, p. 1014) has subsequently referred to this as a separate 'condition of autonomy' or 'independence condition', which must be satisfied along with the normal justification thesis in order for an authority to be legitimate. ${ }^{5}$

This covers the accepted understanding of Raz's theory. I turn now to an interpretive point within the theory. The original formulation of the normal justification thesis argues that authority is established by comparing an institution to individuals acting by themselves. But this does not address situations where there are several institutions with a claim to authority. In a pregnant comment Raz says that:

One recurring kind of reason against accepting the authority of one person or institution is that there is another person or institution with a better claim to be recognized as an authority ( $\operatorname{Raz} 1986$, p. 57).

This suggests that an institution does not have authority if there is an alternative institution that better fulfils the normal justification thesis. ${ }^{6}$ Consequently it seems possible that an institution could be better than individuals acting on their own but does not have authority because an alternative institution is even better than the first.

\footnotetext{
${ }^{5}$ Simmons (1999) has argued that we should distinguish between the justification and the legitimacy of the state. A state is legitimate if it has authority, whereas a state is justified if it is 'rationally preferable to all feasible non-state alternatives' (1999, pp. 742 \& 746). A state can therefore, according to Simmons, be justified without being legitimate (in that it is all things considered preferable but there is no obligation to obey it). In Raz's theory an institution cannot be legitimate if it is not justified, because (as I will show) if an institution is not better than its alternatives then it does not have authority. Raz (1989, pp. 1180-1181) however also says that an institution can be justified, because it passes the normal justification thesis, but is not a legitimate authority, because it fails the independence condition. In Raz's theory then, justification is a necessary but not sufficient condition for legitimate authority. In terms of my argument we can see that political anarchism is primarily a claim about the justification of the state, since it claims that anarchism is a better alternative to the state. But the point of my argument is to show that, if we accept Raz's theory of authority, political anarchism can also affect the legitimacy of the state.

${ }^{6}$ See also Raz's (1989, p. 1180) later remark that an institution has authority when it 'makes compliance with its directives closer to reason than either compliance with a less efficient institution or acting independently'.
} 
This constraint, Raz (1986, p. 57) says, will only apply when 'two authorities are incompatible, as are the claims of two governments to be legitimate governments of one country'. Raz has subsequently addressed in greater depth the possibility of conflicting alternative institutions claiming authority:

At other times authorities may be hostile to each other, directing their subjects not to obey, and more generally not to cooperate with the working of other authorities. In such cases the question whether a given authority's power extends to exclude the authority of another is to be judged in the way we judge the legitimacy of its power on any matter, namely, whether we would conform better to reason by trying to follow its directives than if we do not ( $\operatorname{Raz} 2006$, p. 1021).

Thus in cases where there are conflicting, even 'hostile', alternative institutions, legitimate authority is assigned to whichever institution enables people to conform better to reason than the alternatives. Legitimate authority is thus allocated to the institution that is 'best' among the alternatives, even if the other institutions might be 'better' than the individuals acting by themselves.

Let us look a little closer at what these alternative institutions with a claim to authority might be. Raz writes that in order to be considered a legitimate authority an institution must be a de facto authority, in that they 'are in fact followed or at least conformed with by considerable segments of the population' (Raz 2006, p. 1036, see also Raz 1986, p. 56). Thus it seems that only alternative institutions that are already de facto authorities, i.e. followed by a large amount of the population, can be candidates for legitimate authority (which I will call existing alternatives). There is a question however, Nicole Roughan argues, as to how we should interpret this condition: a 'strict reading would limit legitimate authority to those bodies that already have effective authority; a looser reading would require that legitimate authority could attach to bodies that could have effective authority' (Roughan 2013, p. 108). In other words, should the service conception only look at existing de facto alternative institutions, or should it also consider possible alternatives, institutions that are not currently followed by large parts of the population but could be.

Roughan points to Raz's (1986, pp. 75-76) statement that the service conception can extend to an institution that 'is soon likely to acquire effective power' as evidence that Raz does slightly open the door to possible alternatives having legitimate authority, i.e. when they are very close to being existing alternatives. But Raz seems to rule out possible alternatives that are further from realisation. Raz for example goes on to say that in a situation where someone claims authority but does not yet have effective power: 'He may deserve to have such authority. It may be better if he acquires it. He may even have a right to it. But he does not yet have it' (Raz 1986, p. 76). This suggests that even when a possible alternative would be better than an existing institution, it does not have authority until it becomes (or is very close to being) an existing alternative. Roughan (2013, p. 108) believes that Raz's position thus strikes a balance between 'not precluding new competitors from being candidates for legitimate authority' and 'helping to deal with the problem that it will sometimes be difficult to work out whether a particular power is or has the capacity to be effective.' 
In contrast, I believe that a theory of authority should take greater account of possible alternatives than this. This is because I think the possibility of a better alternative should play an important role in delegitimizing existing institutions. Yet it would take us too far from Raz's commitment to a legitimate authority being a de facto authority to argue that a possible alternative could completely delegitimize an existing institution. But it is, I think, broadly faithful to the central features of the service conception to limit an existing institution's authority in one crucial respect. Consider the case of when an existing authority is hostile to a better possible alternative, to the extent that it actively uses its authority to prohibit or obstruct the promotion or establishment of the possible alternative. By granting the existing institution legitimate authority we are seemingly committed to obeying directives that stop the emergence of a better alternative. Obeying these directives would in this case fail to live up to the central motivation behind the service conception: bringing people closer to reason. I therefore think that the authority of an existing institution should not extend to areas concerning the promotion or establishment of a better possible alternative. ${ }^{7}$

Interpreting the service conception in this way ensures that we do not grant existing institutions so much authority that it precludes the possibility of better alternatives emerging. Considering only existing alternatives would I think exhibit an unwarranted bias towards the status quo and potentially foreclose challenges to it. Though it should be noted that, under the service conception, existing institutions will still have legitimate authority in those areas not affected by this consideration.

\section{Philosophical and Political Anarchism}

Let us now turn to philosophical and political anarchism. Philosophical anarchism denies that the state has authority. It is most commonly associated with Robert Paul Wolff's short but influential In Defense of Anarchism (1970). ${ }^{8}$ Wolff argued that people's primary moral obligation is to be autonomous, to obey only their own moral laws. The state however claims authority over people so that they must obey its directives. There is therefore a clash between the state's authority and the autonomy of the individual. Consequently, Wolff claims, a legitimate state (where people are obligated to obey its directives) is impossible. Wolff's argument has however been subjected to a number of criticisms. One problem highlighted by Raz (1990, p. 12), is that its strong account of autonomy strikes many as 'exaggerated'. As Raz points out, it is consistent with autonomy to sometimes defer to others if that will help you achieve what you wanted to do anyway. In the case of the state's authority, a common line of thinking is that because the state allows people to realize what they could not achieve by themselves, then all things considered the

\footnotetext{
7 I do not of course expect the existing authority to respect or recognize that its authority is limited in this way. It is instead aimed at those subject to the authority who should see themselves as not obligated to follow the authority's directives in these matters.

8 A more sophisticated account of philosophical anarchism is given by Simmons (1979), where his approach is to show that some of the main theories of authority (consent, tacit consent, fair play, duties of justice, and gratitude) all fail to establish the authority of the state.
} 
state is legitimate, even if it might potentially conflict with a strong view of autonomy. One of the strengths of Raz's theory is that it provides a convincing reply to Wolff's philosophical anarchism by capturing this common belief in a philosophical framework.

Political anarchism on the other hand is the claim that anarchism is a better alternative to the state. ${ }^{9}$ It is therefore a view about existing structures and the desirability of changing them, and is one the central contentions of anarchist social and political movements. Philosophical anarchism is however primarily a philosophical position within a philosophical debate. This kind of distinction is common in the literature (Gordon 2005, p. 148; Miller 1984, pp. 15-29; Pateman 1979, pp. 135-142; Simmons 1987, p. 269; 1996, p. 23). It helps distinguish between ideas that share a name and a superficial resemblance but are importantly distinct. Indeed, in stark contrast to political anarchism, philosophical anarchism is compatible with still believing in the need for a state. Wolff (1970, p. 18) for example accepts that the philosophical anarchist may not think that there is 'any real prospect of eliminating the state as a human institution' and Simmons (1987, p. 269) says that it is 'compatible with the view that government may be necessary and that certain types of governments ought to be supported'. It is this lack of political consequences that led David Miller to label philosophical anarchism a 'rather bloodless' position (Miller 1984, p. 15).

Political anarchism then is the claim that anarchism is a better alternative to the state, and in the language of Raz's service conception we can say that it claims that anarchism is better at enabling people to conform with reason than the state. This raises the question of what I mean by the 'state' and 'anarchism'. For the state I adopt the standard definition as a (i) centralised and hierarchical organisation with (ii) a monopoly on coercion over a given territory. In contrast, by anarchism I mean a form of social and political organisation that (i) is decentralised and nonhierarchical, (ii) does not have institutionalised and extensive means of coercion, and (iii) has democratic control over the means of production. This conception of anarchism is consequently anti-statist and anti-capitalist. ${ }^{10} \mathrm{I}$ contrast the state with this thicker conception of anarchism, rather than with just anti-statism, because it reflects the historical understanding of anarchism and is important to understanding how anarchism might be better than the state. Anarchism is anti-statist in so far as it opposes both capitalist and communist states, largely because the centralised and hierarchical nature of all states allows a ruling class to use the coercive machinery of the state to maintain its position. But a conception of anarchism that does not also take a view on the social and economic organisation of society can have only a limited conception of how it will be a better alternative to the state.

\footnotetext{
9 I do not focus on an additional important idea associated with political anarchism that believing in this alternative obligates one to actively oppose the state because it is less relevant to the ensuing discussion.

${ }^{10}$ It therefore does not cover right-wing 'anarcho-capitalist' varieties of anarchism. These varieties of anarchism are also anti-statist but want the means of production to remain in private hands. Though I cannot defend the view here, I believe that anarcho-capitalism reproduces the exploitative and dominatory economic and social structures of capitalism without the modest welfare provisions and legal protections of the state, and is consequently worse than the state. It therefore does not fulfil the political anarchist claim of anarchism being a better alternative to the state.
} 
Historically the anarchist movement emerged as a distinct social and political movement from within the broader socialist movement, and particularly from within the First International, in the 1860s. The anarchist movement explicitly saw itself as a form of socialism, in that it aimed to overthrow capitalism through class struggle, but it opposed the statist tendencies of other varieties of socialism. It therefore rejected the idea that capitalism could be overthrown by seizing state power and instead advocated organising class struggle outside of and in opposition to the state. Some of the key figures associated with this early political and theoretical development of anarchism include Mikhail Bakunin, Peter Kropotkin and Emma Goldman. The movement gained particular prominence and influence in Spain in the 1930s, but was influential in workers and peasant struggles across the world throughout the late 19th and early 20th century. ${ }^{11}$ By the end of the Second World War it had however been mostly wiped out by communist and fascist dictatorships. But its ideas re-emerged with the 1960s students' and workers' protests, and its contemporary influence can be found in the Zapatistas in Mexico, various antiracist, feminist and queer liberation movements, the alter-globalisation movement (Gordon 2008, pp. 29-31; Graeber 2002), and the numerous social protest movements that have arisen in the aftermath of the global financial crisis (Gibson 2013; Graeber 2013).

There are, I believe, several historical and contemporary examples of large-scale societies that meet the description of anarchism as a form of social and political organisation that is (i) decentralised and non-hierarchical, (ii) does not have institutionalised and extensive means of coercion, and (iii) has democratic control over the means of production. These features were, as I will discuss below, at one point widely realised by the anarchist collectives during the Spanish civil war. A further example, are the areas under anarchist control during the Ukrainian revolution and civil war from 1917 to 1921. In these areas, anarchists, known as 'Makhnovists', began organising free soviets and communes based on peasant and worker self-administration, across a territory with a population of several million people, whilst simultaneously fighting both the White and Red armies (Malet 1982, pp. 107-125; Marshall 1992, pp. 473-475; Shubin 2010). In addition, the Zapatistas have been largely autonomous from the Mexican state since their 1994 rebellion. They consist of more than a thousand self-governing communities in a region of about 300,000 people. They provide educational, health, and judicial services, with political decisions made through a set of community, municipal, and regional assemblies, and they organise the local economy through agricultural and smallscale industrial collectives and cooperatives (Híjar González 2008; Starr et al. 2011, pp. 104-108; Stahler-Sholk 2007, pp. 54-60). ${ }^{12}$ These examples of anarchist organisation across a large-scale society meet the definition of an existing or de

\footnotetext{
${ }^{11}$ This understanding and history of anarchism is indebted to the approach taken by Schmidt and van der Walt (2009). For an overview of anarchism's less well-known influence outside of Western Europe during this period see the edited volume by Hirsch and van der Walt (2010).

12 Though the Zapatista communities thus display many anarchist features it is important to note that their ideas and practices are influenced by a number of traditions including, Indigenous philosophies and autonomous Marxism.
} 
facto alternative in that they were/are followed by a considerable proportion of territory's population.

Furthermore, the features of anarchism highlighted above can also apply to groups within states. Cooperatives, collectives, trade unions, and social movements can all be described as anarchist (and as more or less anarchist) based on the extent to which they realise the features highlighted above. This understanding of anarchism, as a form of social and political organisation rather than just a utopian ideal, is often associated with Colin Ward who argued that anarchism:

is always in existence, like a seed beneath the snow...far from being a speculative vision of a future society, it is a description of a mode of human organisation, rooted in the experience of everyday life, which operates side by side with, and in spite of, the dominant authoritarian trends of our society (Ward 1973, p. 11).

Anarchist groups that are organised along the features outlined above can therefore exist within the state. Though they do not meet the definition used here of an existing alternative to the state, in that they are followed by a large part of the population, they could have authority in those areas in which they operate if they perform better than the state.

\section{The Challenge of Political Anarchism}

Having set out these definitions we are in a position to turn to the political anarchist challenge to the authority of the state. The most straightforward way to use Raz's theory of authority to justify the authority of the state is to argue that the state is an institution that fulfils the conditions of the service conception and therefore the state has authority. Raz however believes that the service conception cannot be applied to the state quite so straightforwardly. He argues that the state's ability to help individuals conform better with reason varies from individual to individual. Where the state is no better than the individual it does not have authority (Raz 1986, p. 78). Furthermore, Raz's independence condition limits the state's authority to only those areas where it is not more important for individuals to decide for themselves. This means that the service conception of authority actually only gives a 'piece-meal' justification of state authority; it will have authority in some areas, over some people, and the extent of that authority will vary from individual to individual (Raz 1986, p. 80). ${ }^{13}$ However, Raz (1986, pp. $100 \& 103$ ) also claims that in spite of these limitations, states still have a 'good deal of common authority...over all [their] subjects regarding a certain range of issues' and that a relatively just state would have 'authority over just about everyone in certain matters.' Thus when I say that political anarchism affects how Raz's theory justifies the state's authority, I mean

\footnotetext{
13 Because Raz (1979) has denied that there is a general duty to obey the law he is sometimes thought of as a philosophical anarchist. However because Raz maintains that the state has 'piece-meal' authority he rejects the philosophical anarchist claim that the state has no authority.
} 
this more limited 'piece-meal' understanding of state authority, which Raz at the same time believes is still fairly extensive.

With this caveat in mind, let us first look at the justification of the state's legitimate authority in cases where anarchism is an existing alternative. The normal justification thesis states that an institution has authority if it is better an enabling people to conform with reason than if it they acted on their own. The state, it is claimed, is an institution that enables people to conform better with reason that if they acted on their own. The state would therefore seemingly have legitimate authority. However, the qualification Raz sets on this is that the institution does not have legitimate authority if there is a better existing alternative institution. Political anarchism claims just that, that in these cases anarchism is a better existing alternative to the state. The state therefore does not have legitimate authority because there is an institution that is even better at enabling people to conform with reason. Thus, in these cases, Raz's theory does not reject philosophical anarchism, it instead assigns legitimate authority to anarchist groups and societies. In order to establish the state's authority in these cases the theory would have to be supplemented by an additional argument that shows that the political anarchist claim is wrong; that the state is in fact better at enabling people to conform with reason than the anarchist groups and societies. Rejecting philosophical anarchism in these cases is therefore reliant on also rejecting political anarchism.

Now let us turn to cases when anarchism is not an existing alternative, but only a possible one. A further qualification we added to Raz's service conception is that an existing institution's authority does not extend to the promotion or establishment of a better possible alternative. If the political anarchist claim is true, and anarchism is in fact a better possible alternative, then the state's legitimate authority will be limited to not preventing the promotion or establishment of anarchism. The extent to which Raz's theory responds to philosophical anarchism in general will thus be weakened if political anarchism is true. This consideration in effect makes the state's authority even more piece-meal, since in addition to the areas noted by Raz, the state now also does not have authority in those areas related to the promotion or establishment of anarchism as a better alternative. ${ }^{14}$

Thus both in cases where anarchism is an existing alternative and when it is only a possible alternative, the state's authority and the extent of that authority is dependent on whether or not political anarchism is true. Raz (1986, p. 70) in fact rejects political anarchism, arguing that the 'existence [of states] is preferable to any alternative method of social organization'. ${ }^{15} \mathrm{He}$ acknowledges however that the application of his theory of authority is 'contingent' on these matters, but (as he rightly points out) this contingency does not affect the service conception of authority itself (Raz 1986, p. 57). My argument thus only questions the application of the service conception to the state, and not the theory as such. Political anarchism in effect drives an empirical wedge between authority and the authority of the state.

\footnotetext{
$\overline{14}$ The state's authority might be even further limited by anarchist groups within the state, which, provided they perform better than the state, will have authority in the relevant areas rather than the state.

${ }^{15}$ Similarly Simmons (2008, p. 64) claims that 'some existing states clearly do enough good (and refrain sufficiently from unwarranted coercion) that they should not be opposed or undermined. Political anarchism...is for that reason false.'
} 
These arguments are therefore empirically contingent on whether or not the claim of political anarchism is true. The primary example that I will present in the next section in support of this claim, are the anarchist collectives during the Spanish civil war. These, I will argue, are an example of anarchism as a better existing alternative to the state. They thereby provide a case of when the state does not have legitimate authority because anarchism is a better existing alternative. By selecting this example I do not however mean to support the idea of 'Spanish exceptionalism', that anarchism was only an important movement in Spain (Schmidt and van der Walt 2009, pp. 273-275). As was discussed earlier, other examples of anarchist organisation across a large territory and population include, but are not limited to, the Ukrainian anarchists from 1917 to 1921 and the Zapatistas. These are also cases where I believe that the state does not have legitimate authority. I have focused on the Spanish collectives however because of my greater familiarity with them and the ready availability of economic and social evidence of them being a better alternative to the state.

The discussion of the Spanish collectives is also supposed to provide suggestive (though of course not definitive) evidence for the claim that anarchism is in general a better possible alternative to the state. Convincingly establishing that claim would require a far more extensive historical and theoretical examination than I have the space to engage in here. That kind of examination would, for example, include engaging with the vast anarchist literature, ranging from Bakunin, Kropotkin and Goldman to Noam Chomsky and Murray Bookchin, for some of the moral and practical arguments for why anarchist forms of organisation are better than statist ones. It would also include examining anthropological work, like that of Scott (1998; 2012), on how the centralised and hierarchical nature of states results in a tendency to disregard and override local social practices and knowledge. Further evidence could be gathered from the experience of groups within the state that have organised themselves along anarchist principles. The work of Ward (1973; see also White 2007) is particularly relevant here, in showing how varous anarchist groups, such as squatter movements, free schools, self-help groups, and housing and credit cooperatives, have emerged to deal with social problems neglected by the state. A complete answer to whether the political anarchist claim is credible would involve examining all these kinds of evidence. The approach I have taken, in the space available to me, is to present an extended example of anarchism in action across a large society because I think this provides a vivid and compelling account of how anarchist organisation can be better than the state. I hope however that the discussion of the Spanish collectives shows why that further examination is worthwhile.

\section{The Spanish Collectives}

On 17 July 1936 nationalist generals began their attempted coup against the Spanish Republic. While the formal institutions of the state dithered, anarchist and socialist trade union militias responded quickly to the attempted coup, securing vital cities, such as Madrid and Barcelona, and territory for the Republic. In this atmosphere 
'the conventional expressions of the centralised state had in most places disappeared' (Thomas 1966: 248), and a social revolution began almost immediately in these areas, with workers seizing control of industry in Barcelona and peasants collectivizing farms across Andalucía, Aragón, Castile, Catalonia, and the Levante. This was not a small-scale experiment. Estimates suggest that there were around 1,500 collectives (Casanova 2005, p. 131; Thomas 1966, pp. 249-250), involving nearly 800,000 people in rural areas and just over a million people in industry (Beevor 2007, p. 123).

The agricultural collectives were formed by expropriating large estates or combining small landholdings (Miller 1984, pp. 161-162). They varied in size from just a few dozen families to some 5,000 people (Thomas 1966, p. 250). The collectives were run by a general assembly consisting of most or all of the collective's members, which decided on the overall direction of the collective, and a smaller administrative council, in charge of its everyday operation (Thomas 1966, pp. 250-251). Distribution methods varied across collectives with some abolishing money and making use of central storehouses from which every member could take what they needed, while others did this with only some basic goods and paid a wage based on family size (Miller 1984, p. 162). In Barcelona the anarchist trade union, Confederación Nacional del Trabajo (CNT), took responsibility for reorganizing industry under worker control. If the old owners remained they were encouraged to stay on as managers supervised by a committee of workers, or if they had fled or been killed, workers would improvise with a variety of management structures (Miller 1984, p. 164). Public utilities were also collectivised with water, gas and electricity all functioning within hours of the trade union militias taking control of the city (Beevor 2007, p. 124).

The social revolution however lasted less than a year. The republican government and communists opposed the working-class and peasant takeover and committed themselves to reasserting centralized control. ${ }^{16}$ The government 'began a policy of bureaucratic harassment of collectivized industry and agriculture' (Preston 1986, p. 120), which gradually reduced the autonomy and effectiveness of the collectives. Finally in May 1937 the anarchists were forcibly overthrown in Barcelona and the agricultural collectives were broken up by communist troops in the summer.

During their brief period of existence the collectives however did an impressive job of meeting people's economic and social needs. Agricultural output, far from collapsing, remained steady or even increased in collectivised areas. Hugh Thomas's (1966, p. 254) in depth survey records that the provinces with the most collectives saw an increase in wheat production between 1936 and 1937 compared to the less collectivised areas, up to $17 \%$ in Castile. Overall agricultural production in Aragón, for example, also increased by $20 \%$ (Beevor 2007, p. 126). The collectives also introduced a number of 'striking' agricultural modernisations to an out-dated farming system (Borkenau 1963 [1937], pp. 102-103; Miller 1984, p. 163; Thomas 1966, p. 254). These were possible because the peasants no longer felt

\footnotetext{
${ }^{16}$ Communist opposition was the result of Joseph Stalin's orders to conceal the social revolution. The communists went so far as to defend private property against worker and peasant control, in order to attract the support of the middle-class and small landholders (Beevor 2007, pp. 122; Preston 1986, pp. 119-120).
} 
threatened by technological change because it was now under their control (Borkenau 1963 [1937], pp. 149-150; Beevor 2007, pp. 123-124).

The performance of collectivised industry in Barcelona is also encouraging. Franz Borkenau, an Austrian sociologist who wrote a first-hand account of the civil war, visited one of the collectivised factories and declared that it is an 'extraordinary achievement for a group of workers to take over a factory, under however favourable condition, and within a few days to make it run with complete regularity' (1963 [1937], pp. 90-91). The industrial collectives were in fact working in an actively hostile political and economic environment. Aside from the effects of the civil war the republican government also refused foreign exchange to collectivised industries, withheld vital credit for investment, and even offered government contracts to foreign companies rather than giving them to the collectivized industries (Beevor 2007, p. 124). Set against this unpropitious economic and political climate the fact that many industries and public services in Barcelona were able to function at least as effectively as they had before the war is impressive. The CNT was also successful in reducing inefficiencies by streamlining a number of smaller workshops into several larger plants (Beevor 2007, p. 124). Miller (1984, p. 164) thus concludes that the CNT's effort to reorganise factory management 'appear[s] to have struck a sensible balance between industrial democracy and the requirements of efficient production.'

The economic successes were matched by the positive social effects brought about by the revolution. Contemporary accounts speak of the liberating atmosphere that existed in those short months. George Orwell in his Homage to Catalonia described his first impressions of Barcelona:

The Anarchists were still in virtual control of Catalonia and the revolution was still in full swing... It was the first time that I had ever been in a town where the working class was in the saddle...Every shop and café had an inscription saying that it had been collectivized... Waiters and shop-walkers looked you in the face and treated you as an equal. Servile and even ceremonial forms of speech had temporarily disappeared...Almost my first experience was receiving a lecture from a hotel manager for trying to tip a lift-boy. There were no private motor cars, they had all been commandeered, and all the trams and taxis and much of the other transport were painted red and black... And it was the aspect of the crowds that was the queerest thing of all. In outward appearance it was a town in which the wealthy classes had practically ceased to exist. Except for a small number of women and foreigners there were no 'well-dressed' people at all. Practically everyone wore rough working-class clothes, or blue overalls, or some variant of the militia uniform. All this was queer and moving...I recognized it immediately as a state of affairs worth fighting for (Orwell 1986 [1938], pp. 2-3).

This social popularity also extended into the rural areas. Borkenau (1963 [1937], p. 167) observed how the members of even a severely impoverished agricultural collective were proud of what their collective had achieved. The experience of selfmanagement and community seems to have contributed greatly to their happiness and sense of personal self-fulfilment (Beevor 2007, p. 126; Miller 1984, p. 167). 
Even Thomas's (1966, p. 263) somewhat sceptical overview concludes, 'there is a good deal of evidence for thinking that they were a considerable social success.' The social revolution provided a brief breath of fresh air for many people in rural communities, especially women, from the boredom and repression of the traditional Catholic lifestyle (Thomas 1966, p. 261). Furthermore, in urban areas women's organisations and publications emerged demanding the 'double emancipation, of the revolutionary proletariat from its capitalist enemies, and of women from gender subordination' (Lannon 1991, p. 223). One of the most prominent groups to emerge was the anarchist-feminist Mujeres Libres, which argued for radical views on sex and the family and encouraged women to join trade unions and become politically active (Lannon 1991, p. 223).

This evidence thereby supports the idea that the collectives were a better alternative to the state. The agricultural and industrial collectives were able to effectively organise economic production and did so to a standard that rivalled the hierarchical capitalist systems maintained previously by the state. ${ }^{17}$ They were socially popular because they freed people from rigid and unequal social relations and allowed them to participate in and exercise democratic control over their political and economic environment. Saying that the anarchist collectives were better than the state of course depends on what independent reasons we think a social system should realize. Raz's theory is modular in the sense that it argues that authoritative directives should be based on reasons that already apply to the subject (the dependence thesis) but does not specify what those reasons should be. The economic and social reasons suggested above are I believe relatively uncontroversial for what we want a social system to achieve. In summary, the Spanish collectives are an example of anarchism replacing the state and, rather than collapsing in failure, they did a better job at enabling people to conform with reason. This is why I think they are compelling evidence for political anarchism.

The evidence from the Spanish collectives is of course not uncontroversial. Thomas (1966, pp. $254 \& 262$ ) believes that it is not possible to come to a definitive conclusion about the efficiency of the agricultural collectives because of the lack of data from this period and the reliability of that data. He also points out that a year is not enough time to judge the success or failure of an agricultural system. Miller (1984, pp. 165-166) argues that while the collectives did a good job of coordinating production and distribution inside the collective, they were less effective at coordinating between cooperatives. He believes that this is general problem with anarchist forms of organisation that shows the necessity of a centralised authority (Miller 1984, p. 173). It also important to not be overly romantic about the collectives, some of them were forcibly imposed by anarchist militias with often innocent peasants suspected of nationalist and fascist sympathies executed en masse (Borkenau 1963 [1937], pp. 97-109). These collectives were, unsurprisingly, much less successful than those that had emerged spontaneously (Beevor 2007, p. 125).

\footnotetext{
17 Even if they had been less economically efficient, Cohen (2009, pp. 73-74) is, I believe, right to say that some reductions in efficiency that could result from more egalitarian communities can be justified by the other values they realize.
} 
The short lifespan of the collectives does limit how much we can infer about anarchism's long-term viability. ${ }^{18}$ It is however important to emphasize that their brief existence was because of the determined opposition and eventual destruction by the republican government and the communists. It was not because they collapsed from internal organisational difficulties or lack of popular support. ${ }^{19}$ Their brief existence cannot therefore be used to prove the opposite thesis, that anarchism's internal organisation makes it unable to perpetuate itself over time. It is also the nature of large-scale changes to societal structures that we cannot know for sure whether they can perpetuate themselves over time until we try them. Nor are some of the coordinating difficulties experienced by the collectives decisive evidence against them. The collectives were subject to constant harassment by the government and 'War was hardly the best context for massive economic experiments' (Preston 1986, p. 118). The fact that they were able to coordinate as well as they did given the hostile circumstances suggests the potential, rather than just the limitations, of anarchist forms of organisation. Given more time and more favourable circumstances it is possible that some of these problems could have been overcome.

In summary, the Spanish collectives are an example of anarchism being a better existing alternative to the state. They should therefore give us pause to re-think the assumption that the state is obviously better than anarchism. They consequently provide some evidence for the general political anarchist claim that anarchism is also a better possible alternative.

\section{Anarchism and Authority}

If we accept the evidence from the Spanish collectives and political anarchism more broadly than we are led to the conclusion that anarchist groups and societies can have authority rather than the state. This might be considered a peculiar consequence. Anarchism in general, and even political anarchism, is often associated with opposing authority in all its forms. This section shows that while there is some tension between the two, authority and anarchism are not irreconcilable.

The association of anarchism with opposing authority runs deep in the anarchist literature. Woodcock (1963, p. 9) for example opens his influential history of anarchism with a quote from Sébastien Faure: 'Whoever denies authority and fights against it is an anarchist'. Similar sentiments are found in the writings of the

\footnotetext{
${ }_{18}$ Raz raised this worry in his response to the argument. He questioned whether anarchist groups and societies can perpetuate themselves over time, which he argued is a vital test for whether an institution is feasible. He accepted that while the collectives were not to blame for their short period of existence, it means that they do not show that anarchism can pass this test. He further thought that the collectives were relying on a state of revolutionary 'euphoria' to ensure compliance, which was neither possible nor desirable to sustain in the long term. The experience of the Zapatistas would be particularly relevant in countering this argument, since they have managed to perpetuate themselves for the last twenty years.

19 Indeed the destruction of the collectives is said to have removed the 'one great and unique weapon the Republic possessed...popular enthusiasm' (Preston 1986, p. 115), which meant that the 'morale of the population was mortally stricken' (Beevor 2007, p. 123).
} 
classical anarchists. Kropotkin (1970 [1897], p. 137 quoted in Pateman 1979, p. 141) for example argued that 'anarchism...works to destroy authority in all its aspects', and Bakunin (1970 [1882], p. 28) expressed the feelings of many anarchists when he declared: 'authority — a word and a thing which we detest with all our heart'. While we should not take these statements as definitive of what political anarchism must stand for, it does suggest that political anarchism, as well as philosophical anarchism, has a problem with authority. Carole Pateman has however argued that this problem is traceable to the confusion of opposing certain authorities with opposing the concept of authority as such. She notes that:

Anarchists have usually been political activists and popular pamphleteers and not concerned with precise conceptual distinctions. They have tended to treat 'authority' as a synonym for 'authoritarian', and so have identified 'authority' with hierarchical power structures, especially those of the state (Pateman 1979, p. 141).

Thus the classical anarchist opposition to authority should more accurately be seen as opposition to authoritarian and hierarchical authorities, rather than authority as such. ${ }^{20}$ By separating the concept of authority from authoritarian and hierarchical authorities it is clear that there is no necessary relationship between political anarchism and opposing authority. Believing that anarchism is a better alternative to the state is thus compatible with believing (or not believing) that there can be legitimate authority. A political anarchist can hold either position and still be a political anarchist. Political anarchists will therefore usually also be philosophical anarchists, in that they deny that the state has legitimate authority, but they do not necessarily have to oppose the idea of legitimate authority as such. ${ }^{21}$

That does not mean that authority is an unproblematic concept for political anarchists. For the purposes of this article I have accepted that Raz's theory is the correct way to justify authority and focused my criticism on the application of the theory. I do not take a stand on whether I think political anarchists should in general believe in authority or indeed if Raz's theory is the best way for political anarchists to justify authority. ${ }^{22}$ I think anarchists have good reasons to be wary of appeals to obedience and authority given how they are often used to mask hierarchical power structures. There is indeed a lot of truth in Goldman's (1972 [1940], p. 92) warning that 'authority of any kind, unavoidably becomes reactionary.' We should therefore be careful to not uncritically rehabilitate the concept of authority.

\footnotetext{
20 This is corroborated by de George (1978, p. 92): "it is not authority as such that the anarchist attacks, his words to the contrary notwithstanding. Rather he implicitly and rightly attacks authoritarianism, which anarchists have tended to equate with established authority.'.

21 See Egoumenides (2014) for a recent attempt to outline a theory of 'critical philosophical anarchism', which combines insights from both philosophical and political anarchism.

22 I think that a theory of authority that is based on inclusive and participatory democratic structures is a more promising way for anarchists to theorize authority. Pateman's (1979, p. 163) account of political obligation is suggestive in this regard, where she argues that a 'relationship of political obligation is possible only in the context of a participatory or self-managing democracy'. For an in-depth survey of anarchism's relationship to authority see also McLaughlin (2007).
} 
But though the 'normal understanding is that authority involves a hierarchical relationship' (Raz 2006, p. 1044) this does not mean that authority can only ever apply to hierarchical institutions. It is not inconceivable that the kind of nonhierarchical association that anarchists envisage could give rise to obligations to follow the collective decisions of that association. Kinna (2005, p. 71) for example argues that if authority is taken as 'authority from below' then 'anarchism is consistent with some forms of binding agreement'. This is also supported by Miller (1984, pp. 15-16), who writes that anarchists can believe in authority but 'may put forward rigorous conditions for legitimate authority, so rigorous that no state can hope to meet them, though other forms of political associations might-say certain kinds of communal self-government'. Even Bakunin (1970 [1882], p. 42n) argued that the 'only...authority... which we may respect, will be that of the collective and public spirit of a society founded on equality and solidarity and the mutual human respect of all its members.' In summary then, political anarchists can believe in nonhierarchical authority, which involves an obligation to follow the decisions of the group or society but where those decisions have been arrived at collectively and democratically, and not by a person or group at the top of a hierarchy.

Consider the case of how the Spanish collectives fulfil the conditions of the service conception of authority. In order to be considered an authority they would have to fulfil the normal justification thesis as well as the dependent thesis and the pre-emptive thesis. As we saw in the previous section, the agricultural collectives had a general assembly where the members would meet in the town or village square to decide on collective matters. One of the things we can imagine them deliberating about is how the various farming tasks should be divided among the collective's members. The eventual decision of the group then acts as an authoritative directive that the members should follow. That authoritative directive would for example correspond with the members' independent reason to have a reliable and efficient supply of food. The collective's authoritative directive thus satisfies the dependent thesis. They also satisfied the normal justification thesis because they did a more effective job of organising agricultural production and thus enabled people to better comply with this reason than the alternatives that had preceded it. Finally, the directives of the collective displace and pre-empt other reasons for action and thereby satisfy the pre-emptive thesis. In this way the collectives would have authority under Raz's service conception. We can therefore see how a non-hierarchical anarchist group can have authority. ${ }^{23}$

A potential difficulty however in ascribing authority to the collectives, and anarchist groups and societies generally, is that it is often thought that authority gives an institution the right to coerce people to comply with its directives. This

\footnotetext{
${ }^{23}$ One referee questioned whether the collectives could really be considered non-hierarchical since there will have been some level of hierarchy in the general assembly and administrative council. This is certainly true; hierarchies would have resulted from gender, age, education and profession. The collectives were to that extent less anarchist. But while the collectives may not have fully lived up to the anarchist principles that they aspired to, real political practices and institutions are always an imperfect attempt to realize these principles. As White (2007, p. 24) notes 'Other ideological families, liberal and socialist, have their utopias, but critics do not necessarily dismiss them on grounds of the utopias they project, it being well-understood that action and achievement can be true to an ideology's core values and yet reasonably fall short of the relevant utopian vision.'
} 
implication is perhaps at the root of much of the anarchist concern with authority. Once we ascribe authority to an anarchist group or society the danger seems to be that it licenses the group or society to use the same tools of coercion that characterise the state. The anarchist group or society would thereby seem to descend into the same kind of problems anarchists have with the state. On the other hand if we deny that authority gives them the right to coerce people then the question arises how else they can ensure compliance with their directives.

It is however important to note that Raz disputes this linking of authority with coercion. He believes that authority is first and foremost a moral appeal to the subject for compliance with the directive (1986, pp. 25-26). Coercion, he argues, is secondary to that. As we saw earlier in Raz's theory authorities must of course have the de facto ability to get people to comply with its directives; otherwise they would not pass the normal justification thesis. Raz (2006, p. 1036) does believe that for 'governments of the kind we are familiar with' this will mean the 'use of force against those who flout certain of their directives.' But the use of coercion is not central to the service conception itself. Raz (2006, p. 1031) says, a 'major, if not the main, factor in establishing the legitimacy of political authorities is their ability to secure coordination', and if an authority is able to secure coordination and compliance without coercion, or at least extensive use of it, then it is still an authority.

Anarchists are in fact not as uniformly opposed to coercion as they are often portrayed. ${ }^{24}$ Schmidt and van der Walt (2009, p. 33) for example argue that 'there is a place for a certain amount of legitimate coercive power, if derived from collective and democratic decision-making.' This does not mean that anarchists are not seriously concerned by the use of coercion. As the earlier definition of anarchism stated, the crucial difference is the extent to which coercion is resorted to and the degree to which it is institutionalised in formal structures such as the police, prisons and a permanent army (Gordon 2008, pp. 67-69). As the anarchist militias and armies in the Spanish civil war show anarchists are also not opposed to using some degree of coercion to establish and defend anarchist societies and groups. These should however remain, as far as possible, temporary and under collective control. Rather than permanently resorting to these institutionalised mechanisms of coercion the emphasis in anarchist theory and practice is instead usually placed on how inclusive and deliberative democratic procedures motivate compliance among participants.

In the case of the Spanish collectives it seems the collectives were able to secure compliance without resorting to the level of coercion associated with the previous regime. The general assembly's power to expel non-cooperating members was for example very rarely needed or exercised (Miller 1984, p. 162). Thomas (1966, p. 263) also comments that 'there does radiate a considerable spirit of generous cooperation without many complaints at breach of privacy and at local tyrannies'. The revolutionary atmosphere, the continuing fight against the fascists, and the fact that the collectives could rely on significant levels of pre-existing class solidarity and community from the workers and peasants (Miller 1984, pp. 162 \& 167), certainly

\footnotetext{
${ }^{24}$ For a typical example of this kind of stereotypical portrayal see Dahl (1989 pp. 37-51).
} 
play an important role in explaining why the collectives were able to secure compliance without resorting to extensive and institutionalized coercion. While the revolutionary atmosphere and the fight against the fascists are not factors that are widely replicable or sustainable; class solidarity, community and the effect of inclusive and deliberative procedures are more general and sustainable ways in which anarchist groups and societies can secure compliance.

\section{Conclusion}

Pateman (1979, p. 6) has argued that the state is 'an unexamined premise of most anglo-american political theory'. By examining that premise we have seen how using Raz's service conception to reject philosophical anarchism can be affected by political anarchism. It has to assume that anarchism is not a better existing or possible alternative to the state. This assumption is I think reflective of a broader trend in political theory. Philosophical anarchism is taken to be the more pressing and interesting question to tackle, while political anarchism is thought easily refutable. The extended discussion of the Spanish collectives aimed to show why there are credible historical grounds for taking political anarchism seriously. Focusing exclusively on philosophical anarchism obscures both this history and the theory of political anarchism. Raz (1986, p. 47) writes that authorities are best understood through their 'ideal functioning'. In closing, I think that when judging the authority of states we should instead look more closely at their actual functioning. This is because the interesting anarchist challenge is political not philosophical.

Acknowledgments For helpful comments on earlier versions of the article I would like to thank Svenja Ahlhaus, Puneet Dhaliwal, Mirjam Müller, Rob Jubb, Tom Parr, Laura Valentini, Andrew Walton and the anonymous referees for Res Publica. I am also grateful to the organisers and participants of the graduate political theory conferences at Warwick and Science Po, and I was particularly fortunate to receive feedback from Joseph Raz at Science Po.

\section{References}

Bakunin, Michael. 1970 [1882]. God and the state. New York: Dover.

Beevor, Antony. 2007. The battle for Spain: The Spanish civil war 1936-1939. London: Phoenix.

Borkenau, Franz. 1963 [1937]. The Spanish cockpit: An eye-witness account of the political and social conflicts of the Spanish civil war. Ann Arbor: University of Michigan Press.

Casanova, Julián. 2005. Anarchism, the republic and civil war in Spain: 1931-1939. London: Routledge. Cohen, G.A. 2009. Why not socialism? Princeton: Princeton University Press.

Dahl, Robert. 1989. Democracy and its critics. New Haven: Yale University Press.

Darwall, Stephen. 2010. Authority and reasons: Exclusionary and second-personal. Ethics 120: 257-278.

De George, Richard T. 1978. Anarchism and authority. In Anarchism: Nomos XIX, ed. J. Roland Pennock and John W. Chapman, 91-110. New York: New York University Press.

Egoumenides, Magda. 2014. Philosophical anarchism and political obligation. London: Bloomsbury.

Ehrenberg, Kenneth. 2011. Critical reception of Raz's theory of authority. Philosophical Compass 6: 777-785.

Gibson, Morgan. 2013. The anarchism of the occupy movement. Australian Journal of Political Science 48: 335-348. 
Goldman, Emma. 1972 [1940]. The individual, society and the state. In Red Emma speaks: Selected writings and speaches by Emma Goldman, ed. Alix Kates Shulman, 86-100. New York: Vintage Books.

Gordon, Uri. 2005. Anarchism and political theory: Contemporary problems. DPhil Thesis, University of Oxford.

Gordon, Uri. 2008. Anarchy alive! Anti-authoritarian politics from practice to theory. London: Pluto Press.

Graeber, David. 2002. The new anarchists. New Left Review 13: 61-73.

Graeber, David. 2013. The democracy project: A history, a crisis, a movement. London: Allen Lane.

Green, Leslie. 1985. Authority and convention. The Philosophical Quarterly 35: 329-346.

Hershovitz, Scott. 2003. Legitimacy, democracy and Razian authority. Legal Theory 9: 201-220.

Hijar González, Christina. 2008. Autonomía Zapatista: otro mundo es posible. Mexico: Arte, Música y Video.

Hirsch, Steven, and Lucien van der Walt (eds.). 2010. Anarchism and syndicalism in the colonial and postcolonial world, 1870-1940: The praxis of national liberation, internationalism and social revolution. Leiden: Brill.

Kinna, Ruth. 2005. Anarchism: A beginner's guide. Oxford: Oneworld.

Krehoff, Bernd. 2008. Legitimate political authority and sovereignty: Why states cannot be the whole story. Res Publica 14: 283-297.

Kropotkin, Peter. 1970. [1897] Anarchism: Its philosophy and ideal. In Kropotkin's revolutionary pamphlets, ed. Roger N. Baldwin, 114-144. New York: Dover.

Lannon, Frances. 1991. Women and images of women in the Spanish civil war. Transactions of the Royal Historical Society 1: 213-228.

Malet, Michael. 1982. Nestor Makhno in the Russian civil war. London: Macmillan.

Marshall, Peter. 1992. Demanding the impossible: A history of anarchism. London: Harper Perennial.

McLaughlin, Paul. 2007. Anarchism and authority: A philosophical introduction to classical anarchism. Aldershot: Ashgate.

Miller, David. 1984. Anarchism. London: J.M. Dent \& Sons.

Orwell, George. 1986 [1938]. The complete works of George Orwell volume six: Homage to Catalonia. London: Secker \& Warburg.

Pateman, Carole. 1979. The problem of political obligation: A critique of liberal theory. Chichester: Wiley.

Preston, Paul. 1986. The Spanish civil war 1936-1939. Chicago: Dorsey Press.

Raz, Joseph. 1979. The obligation to obey the law. In The authority of law: Essays on law and morality, ed. Joseph Raz, 233-249. Oxford: Oxford University Press.

Raz, Joseph. 1986. The morality of freedom. Oxford: Oxford University Press.

Raz, Joseph. 1989. Facing up: A reply. Southern California Law Review 62: 1153-1235.

Raz, Joseph. 1990. Introduction. In Authority, ed. Joseph Raz, 1-19. New York: New York University Press.

Raz, Joseph. 2006. The problem of authority: Revisiting the service conception. Minnesota Law Review 90: 1003-1044.

Roughan, Nicole. 2013. Authorities: Conflicts, cooperation and transnational legal theory. Oxford: Oxford University Press.

Schmidt, Michael, and Lucien van der Walt. 2009. Black flame: The revolutionary class politics of anarchism and syndicalism. Oakland: AK Press.

Scott, James C. 1998. Seeing like a state: How certain schemes to improve the human condition have failed. New Haven: Yale University Press.

Scott, James C. 2012. Two cheers for anarchism: Six easy pieces on autonomy, dignity, and meaningful work and play. Princeton: Princeton University Press.

Shubin, Aleksandr. 2010. The Makhnovist movement and the national question in the Ukraine, 1917-1921. In Anarchism and syndicalism in the colonial and postcolonial world, 1870-1940: The praxis of national liberation, internationalism and social revolution, ed. Steven Hirsch, and Lucien van der Walt, 147-191. Leiden: Brill.

Simmons, A.John. 1979. Moral principles and political obligation. Princeton: Princeton University Press.

Simmons, A.John. 1987. The anarchist position: A reply to Klosko and Senor. Philosophy \& Public Affairs 16: 269-279.

Simmons, A.John. 1996. Philosophical anarchism. In For and against the state: New philosophical readings, ed. John T. Sanders, and Jan Narveson, 19-39. Maryland: Rowman \& Littlefield. 
Simmons, A.John. 1999. Justification and legitimacy. Ethics 109: 739-771.

Simmons, A.John. 2008. Political philosophy. New York: Oxford University Press.

Starr, Amory, María Elena Martínez-Torres, and Peter Rosset. 2011. Participatory democracy in action: Practices of the Zapatistas and the Movimento Sem Terra. Latin American Perspectives 38: 102-119.

Stahler-Sholk, Richard. 2007. Resisting neoliberal homogenization: The Zapatista autonomy movement. Latin American Perpectives 34: 48-63.

Thomas, Hugh. 1966. Anarchist agrarian collectives in the Spanish civil war. In A century of conflict 1850-1950: Essays for A.J.P. Taylor, ed. Martin Gilbert, 247-263. London: Hamish Hamilton.

Ward, Colin. 1973. Anarchy in action. London: George Allen and Unwin.

White, Stuart. 2007. Making anarchism respectable? The social philosophy of Colin Ward. Journal of Political Ideologies 12: 11-28.

Wolff, Robert Paul. 1970. In defense of anarchism. New York: Harper \& Row.

Woodcock, George. 1963. Anarchism: A history of libertarian ideas and movements. Harmondsworth: Penguin. 